\title{
PENGARUH ATRIBUT PRODUK KOPI BUBUK INSTAN INDOCAFE TERHADAP KEPUASAN DAN LOYALITAS KONSUMEN DI KOTA PONTIANAK
}

\author{
Dita Arista*, Eva Dolorosa, Anita Suharyani \\ Program Studi Agribisnis, Fakultas Pertanian, Universitas Tanjungpura \\ Jl. Prof. Hadari Nawawi, Pontianak \\ *Corresponding author: ditaarista12@gmail.com
}

\begin{abstract}
This research aims to figure out the influence of the product attributes of Indocafe and the effect on customer satisfaction and loyalty in Pontianak city. The determination of the research location is determined intentionally (purposive method) in the city of Pontianak. The study used survey method with 150 respondents by using purposive sampling. Types of data used in this study are primary data and secondary data. Furthermore, the analysis is done by using structural equation modeling. The results showed that the variable of price, quality and packaging affect customer satisfaction. At the same time, quality has a significant effect to consumer loyalty. The most considerable influence on the quality variables and the overall contribution was the performance. Manufacturers need to improve the quality attributes, meaning the composition or content, the balanced flavor between sweet, sour and bitter, and the aftertaste that can last a long time so that consumers can have a good impression of Indocafe.
\end{abstract}

Keywords: product attributes, Indocafe, customer satisfaction, customer loyalty, Structural Equation Modeling (SEM)

\begin{abstract}
Abstrak: Penelitian ini bertujuan untuk menguji pengaruh atribut produk Indocafe terhadap kepuasan dan loyalitas konsumen di Kota Pontianak. Penentuan lokasi penelitian ditentukan secara sengaja (purposive method) yaitu di Kota Pontianak. Penelitian ini menggunakan metode survey dengan 150 responden secara purposive sampling. Jenis data yang digunakan dalam penelitian ini berupa data primer dan data sekunder. Analisis menggunakan Structural Equation Modelling. Hasil penelitian menunjukkan bahwa variabel harga, kualitas dan kemasan berpengaruh terhadap kepuasan konsumen. Sedangkan kualitas berpengaruh signifikan terhadap loyalitas konsumen. Pengaruh paling besar terdapat pada variabel kualitas dan secara keseluruhan kontribusi indikator paling besar terdapat pada indikator performance. Produsen perlu meningkatkan atribut kualitas pada bagian atribut komposisi atau kandungan, taste yang balance antara rasa manis, asam dan pahit, flavor dan aftertaste yang dapat bertahan lama sehingga membuat konsumen dapat memiliki kesan yang baik pada "Indocafe".
\end{abstract}

Kata Kunci: atribut produk, Indocafe, kepuasan konsumen, loyalitas konsumen, Structural Equation Modelling (SEM)

\section{PENDAHULUAN}

Atribut produk yang bermutu merupakan faktor yang sangat penting dalam mempengaruhi kepuasan konsumen. Menurut Kotler dan Keller (2009) kepuasan konsumen merupakan perasaan senang atau kecewa seseorang yang timbul karena membandingkan kinerja yang dipersepsikan produk (hasil) terhadap ekspektasi mereka. Jika kinerja sesuai ekspektasi, konsumen akan merasa puas, 
sebaliknya jika kinerja tidak sesuai dengan ekspektasi, konsumen tidak akan puas.

Perusahaan perlu menjadikan kepuasan konsumen sebagai tujuan awal untuk mencapai loyalitas konsumen dalam suatu persaingan dengan kompetitor yang menghasilkan produk sejenis lainnya. Ketika suatu produk berhasil memberikan kepuasan sesuai kebutuhan atau keinginan konsumennya, maka produk tersebut dapat menumbuhkan ikatan loyalitas, ikatan tersebut akan sangat sulit bagi kompetitor sejenis lainnya untuk merebut hati konsumen, hal ini dikarenakan bahwa konsumen telah mempunyai komitmen serta sikap yang positif terhadap produk tersebut (Solomon, 2002).

Produk yang sesuai dengan keinginan dan kebutuhan konsumen akan mampu bertahan dalam persaingan sehingga dapat memberikan kepuasan pada konsumen, dengan konsumen puas akan produk maka besar kemungkinan konsumen melakukan pembelian kembali produk yang sama.

Menurut Utama et al., (2009) adanya atribut produk yang diberikan terhadap produk maka akan mampu menarik konsumen untuk melakukan keputusan pembelian dan diharapkan konsumen akan puas menggunakan produk sehingga mereka akan loyal dan menjadi pelanggan setia. Atribut produk memiliki peranan yang penting sebagai upaya dalam menciptakan kepuasan konsumen. Konsumen memandang produk sebagai himpunan atribut dengan kemampuan beragam, dalam hal ini memberikan manfaat yang dicari dan memuaskan. Oleh karena itu, perusahaan dituntut supaya menciptakan dan menghasilkan produk yang bisa memenuhi seluruh keinginan konsumen, sehingga produk tersebut akan terus dikonsumsi.

Ketatnya persaingan diantara pemain dalam industri, mengharuskan setiap produsen mempunyai strategi bisnis yang tepat dan terus melakukan banyak inovasi agar bisa naik baik dari segi volume penjualan atau keuntungan yang diharapkan mampu mengatasi persaingan secara global.

Industri minuman merupakan salah satu industri yang mengalami persaingan yang sangat ketat. Hal ini disebabkan oleh berbagai faktor yaitu banyaknya pemain dalam industri yang berlomba-lomba agar tetap mampu bertahan dan bersaing di pasar global serta tingginya permintaan konsumen terhadap produk tersebut. Dari berbagai macam industri yang ada di Indonesia, industri kopi merupakan salah satu industri yang berkembang secara signifikan setiap tahun dan merupakan minuman penyegar yang paling sering dikonsumsi. Hal ini menjadi tantangan bagi pemasar dalam mempertahankan pangsa pasarnya (Sugianto et al., 2013).

Banyaknya merek produk kopi bubuk instan yang beredar sekarang membuat semua merek berupaya menarik perhatian konsumen dengan melakukan berbagai inovasi, perombakan atau perbaikan dari segi atribut untuk mendapatkan hasil terbaik dan dapat menciptakan hubungan yang kuat antara konsumen dengan merek yang dipakainya dan akhirnya tercipta hubungan jangka panjang (Kotler dan Amstrong, 2006).

Salah satu produk yang menunjukkan adanya perubahan penguasaan market share adalah "Indocafe". Indocafe selalu memimpin pangsa pasar sejak tahun 2012-2017 (Top Brand Award, 2020). Keunggulan produk "Indocafe" antara lain memiliki keragaman produk sekaligus pengekspor kopi instan terbesar di Indonesia serta diraihnya penghargaan top brand index pada tahun 2012 sampai tahun 2017 dan ICSA (Indonesian Custumer Satisfaction Award Index).

Pada tahun 2017 Indocafe masih memimpin pangsa pasar dengan memiliki persentase sebesar $20 \%$. Namun persentase ini selalu mengalami penurunan signifikan dari tahun ke tahun yang mana pada tahun 2019 Indocafe hanya memimpin sebesar $15 \%$. Penurunan ini diakibatkan oleh semakin menguatnya produk sejenis lainnya yang mengakibatkan Indocafe tidak bisa mempertahankan posisinya di pasar dan memenangkan persaingan dibandingkan pendatang baru. Hal ini merupakan masalah yang harus dibuat strateginya agar produk Indocafe tetap diminati oleh para konsumen karena semakin banyaknya perusahaan dengan memproduksi produk sejenis yang selalu berupaya untuk menguasai pasar.

Atribut produk merupakan salah faktor yang meningkatkan loyalitas konsumen baik secara langsung maupun maupun melalui kepuasan. Atribut produk dapat mempengaruhi kepuasan, sehingga membuat konsumen dapat menerima produk tersebut dan melakukan pembelian ulang (Lilja, 1994). 
Manfaat produk dikomunikasikan dan disampaikan oleh atribut produk untuk memperoleh kepuasan dan loyalitas konsumen, Keputusan mengenai atribut produk sangat penting dalam mempengaruhi reaksi konsumen terhadap suatu (Engel et al., 2001).

Strategi mengembangkan produk melalui Atribut Produk dirasa sangat perlu untuk memberikan kepuasan dan menjaga loyalitas konsumen, karena memiliki konsumen yang loyal terhadap produk akan menimbulkan banyak keuntungan. Dengan memiliki konsumen yang loyal akan memerlukan sedikit pengorbanan dibandingkan harus mencari konsumen baru. Berdasarkan fenomena yang telah dikemukakan, maka perlu dilakukan penelitian mengenai penentapan atribut produk kopi bubuk instan Indocafe terhadap kepuasan dan loyalitas konsumen di Kota Pontianak. Kota Pontianak merupakan merupakan wilayah yang memiliki jumlah penduduk terbesar di Kalimantan Barat dengan dengan tingkat konsumtif yang tinggi (Badan Pusat Statistik, 2019). Adapun tujuan dari penelitian ini adalah untuk mengembangkan atribut kopi bubuk instan "Indocafe" agar memperoleh kepuasan dan loyalitas konsumen di Kota Pontianak.

\section{METODE PENELITIAN}

Penentuan lokasi penelitian ditentukan secara sengaja (purposive method) yaitu di Kota Pontianak dengan pertimbangan bahwa lokasi tersebut merupakan wilayah yang memiliki jumlah penduduk besar dengan tingkat konsumtif yang tinggi.

Metode penelitian merupakan kategori penelitian kuantitatif dengan metode survey. Metode survey dilakukan dengan pengumpulan data menggunakan instrument kuisioner untuk memperoleh tanggapan responden.

Metode penarikan sampel adalah non probability sampling yaitu tidak memberi peluang bagi setiap anggota ataupun populasi dengan menggunakan purposive sampling dengan kriteria yaitu konsumen yang pernah mengkonsumsi kopi bubuk instan Indocafe dan konsumen berusia minimal 17 tahun karena dianggap sudah mampu dalam memahami pertanyaan dan sudah rasional dalam pengambilan keputusan.

Jenis data yang digunakan dalam penelitian ini berupa data primer dan data sekunder. Data primer diperoleh secara langsung dari responden melalui hasil wawancara sedangkan data sekunder diperoleh atau dikumpulkan dariberbagai bahan referensi maupun laporan lain yang telah dipublikasikan sebelumnya. Data sekunder didapatkan melalui Susenas meliputi Tingkat Pertumbuhan Konsumsi Perkapita Bahan Minuman dan Frontier Group berupa data Top Brand Award kategori kopi bubuk instan.

Data yang telah diperoleh di input dan ditabulasikan pada Microsoft Excel yang selanjutnya dianalisis menggunakan Package for the Social Sciences (SPSS) untuk mengukur tingkat validitas dan reabilitas item pertanyaan yang diajukan kepada responden. Pengukuran keabsahan item pertanyaan dilanjutkan dengan analisis Structural Equation Modeling (SEM) untuk memperoleh nilai t-value, Estimates, Standar Solution, Loading Factor, Modification Indices, Structural Equations, Total and Indirect Effects dan Goodness of Fit Statistics.

Untuk mengetahui atribut produk kopi instan Indocafe terhadap kepuasan dan loyalitas konsumen digunakan analisis Structural Equation Modeling (SEM) dengan program Lisrel 8.80. Analisis Structural Equation Modeling (SEM) merupakan analisis multivariate, yaitu kombinasi antara regresi berganda dan analisis faktor sehingga dapat diketahui permodelan interaksi, variabel bebas yang berkorelasi, hubungan banyak indikator dan kesalahan pengukuran.

\section{HASIL DAN PEMBAHASAN}

Karakteristik umum responden dirincikan ke dalam tiga golongan yaitu sosial ekonomi, kebiasaan dan kemampuan dalam menjangkau produk. Karakteristik responden yang dibahas dalam penelitian ini yaitu jenis kelamin, usia, pendidikan terakhir, status pernikahan, status pekerjaan, jumlah anggota keluarga, pendapatan, jenis kopi yang dibeli, frekuensi pembelian dan jumlah dalam setiap pembelian. 
Arista, D., Dolorosa, E., Suharyani, A.: Pengaruh Atribut Produk Kopi Bubuk ...

Tabel 1. Karakteristik responden

\begin{tabular}{|c|c|c|c|}
\hline Karakteristik & Keterangan & Jumlah (Orang) & Persentase $(\%)$ \\
\hline \multirow[t]{2}{*}{ Jenis Kelamin } & Laki-laki & 86 & 57 \\
\hline & Perempuan & 64 & 43 \\
\hline \multirow[t]{5}{*}{ Usia } & $\leq 17-25$ tahun & 60 & 40 \\
\hline & $\leq 26-35$ tahun & 36 & 24 \\
\hline & $\leq 36-45$ tahun & 34 & 22 \\
\hline & $\leq 46-55$ tahun & 14 & 10 \\
\hline & $\geq 56$ tahun & 6 & 4 \\
\hline \multirow[t]{4}{*}{ Pendidikan Terakhir } & SD & 5 & 4 \\
\hline & SMP & 17 & 11 \\
\hline & SMA & 94 & 62 \\
\hline & Perguruan Tinggi & 34 & 23 \\
\hline \multirow[t]{2}{*}{ Status Pernikahan } & Menikah & 73 & 49 \\
\hline & Belum menikah & 77 & 51 \\
\hline \multirow[t]{5}{*}{ Status Pekerjaan } & Pegawai Negeri & 6 & 4 \\
\hline & Pegawai Swasta & 16 & 10 \\
\hline & Wiraswasta & 59 & 40 \\
\hline & Ibu Rumah Tangga & 15 & 10 \\
\hline & Pelajar/Mahasiswa & 54 & 36 \\
\hline \multirow[t]{4}{*}{ Jumlah Anggota Keluarga } & $1-2$ Orang & 17 & 11 \\
\hline & 3-4 Orang & 76 & 51 \\
\hline & $5-6$ Orang & 45 & 30 \\
\hline & $>6$ Orang & 12 & 8 \\
\hline \multirow[t]{3}{*}{ Anggota Keluarga Sudah Berkerja } & 1-2 Orang & 125 & 83 \\
\hline & $3-4$ Orang & 22 & 15 \\
\hline & $5-6$ Orang & 3 & 2 \\
\hline \multirow[t]{5}{*}{ Pendapatan (Rp/Bulan) } & $<2.000 .000$ & 60 & 40 \\
\hline & $2.000 .000-3.000 .000$ & 67 & 44 \\
\hline & $4.000 .000-5.000 .000$ & 13 & 9 \\
\hline & $6.000 .000-7.000 .00$ & 6 & 4 \\
\hline & $>7.000 .000$ & 4 & 3 \\
\hline \multirow[t]{4}{*}{ Jenis Kopi yang dibeli } & Indocafe Cappuccino & 113 & 75 \\
\hline & Indocafe Coffe Mix 3 in & 34 & 23 \\
\hline & 1 & 3 & 2 \\
\hline & Indocafe Ginseng Sereal & & \\
\hline \multirow[t]{3}{*}{ Frekuensi Pembelian (Kali/bulan) } & 1-2 Kali & 75 & $\mathbf{5 0}$ \\
\hline & 3-5 Kali & 50 & 33 \\
\hline & $>5$ Kali & 25 & 17 \\
\hline \multirow[t]{5}{*}{ Jumlah Setiap Pembelian (Bks) } & $1-2 \mathrm{bks}$ & 43 & 29 \\
\hline & 3-4 bks & 52 & 35 \\
\hline & $5-6 \mathrm{bks}$ & 12 & 8 \\
\hline & $7-8 \mathrm{bks}$ & 5 & 3 \\
\hline & $>8 \mathrm{bks}$ & 38 & 25 \\
\hline
\end{tabular}

Sumber: Data Primer Diolah, 2020

\section{Jenis Kelamin}

Secara umum pada karakteristik sosial ekonomi yang paling banyak terlibat dalam penelitian ini didominasi oleh kaum laki-laki sebanyak 86 orang $(57 \%)$. Hal ini menunjukkan bahwa proporsi laki-laki memiliki kebiasaan mengkonsumsi kopi yang lebih besar karena menurutnya mengkonsumsi kopi merupakan pilihan yang tepat dan banyak memberikan manfaat. Sedangkan perempuan biasanya lebih tertarik pada kategori minuman yang lebih manis seperti jus, susu atau sari buah.

\section{Usia}

Berdasarkan kelompok usia, responden didominasi oleh kelompok usia yakni 17-25 tahun sebesar 60 orang (40\%). Hal ini menunjukkan bahwa konsumen pada usia muda lebih terbiasa dan suka mengkonsumsi 
minuman kopi bubuk instan, selain itu pada usia tersebut berada pada usia yang produktif.

\section{Tingkat Pendidikan}

Pada kategori tingkat pendidikan, responden yang paling banyak adalah lulusan SMA yaitu 94 orang $(62 \%)$. Hal tersebut menunjukkan bahwa konsumen kopi instan didominasi oleh konsumen dengan tingkat pendidikan menengah atas. Konsumen yang berpendidikan terakhir SMA sudah termasuk dalam kualifikasi dalam mendapatkan pekerjaan. Penelitian oleh Solikatun et al. (2015) serta Yulianti dan Deliana (2018) menunjukkan bahwa tingkat pendidikan akan berpengaruh terhadap pengetahuan, penerimaan dan perilaku seseorang karena berhubungan dengan daya nalar, pengalaman dan kejelasan mengenai objek tertentu.

\section{Status Pernikahan}

Status pernikahan merupakan status responden berdasarkan riwayat pernikahan yang sesuai dengan catatan sipil. Hasil penelitian menunjukan karakteristik responden berdasarkan status pernikahan didominasi oleh responden yang belum menikah yaitu sebesar 77 orang $(51 \%)$. Hal ini dikarenakan mayoritas kopi bubuk instan dalam bentuk sachet lebih banyak digemari oleh kaum muda dimana individu tersebut sebagian besar berstatus wiraswasta muda serta masih duduk dibangku perguran tinggi, keputusan pembelian kopi bubuk instan terhadap konsumen yang belum menikah merupakan keputusan yang dipengaruhi oleh diri sendiri, karena terdapat keinginan untuk mengkonsumsi produk tersebut baik digunakan sebagai minuman penyegar dan untuk beraktivitas.

\section{Status Pekerjaan}

Karakteristik responden bardasarkan jenis pekerjaan didominasi oleh responden yang bekerja sebagai wiraswasta, dengan jumlah responden sebanyak 59 orang (40\%). Hal tersebut dikarenakan konsumen pada golongan tersebut mempunyai kesibukan yang tinggi sehingga lebih menyukai hal-hal yang praktis dan lebih memilih kopi instan untuk di konsumsi agar tidak menyita waktu dibandingkan dengan harus mengolah secara langsung.

\section{Jumlah Anggota Keluarga}

Jumlah anggota keluarga sangat menentukan jumlah kebutuhan keluarga. Semakin banyak anggota keluarga berarti semakin banyak pula jumlah kebutuhan keluarga yang harus dipenuhi. Begitu pula sebaliknya. Responden berdasarkan jumlah anggota keluarga didominasi oleh konsumen yang beranggotakan 3-4 orang lebih dominan yaitu sebanyak 76 responden (51\%) dengan jumlah anggota keluarga yang sudah bekerja yaitu beranggotakan 1-2 orang sebanyak 125 responden (83\%). Hal ini menunjukkan bahwa jumlah keluarga akan mempengaruhi keputusan pembelian, yang mana terdapat berbagai keputusan yang akan mempengaruhi di dalam keluarga serta dapat meningkatkan daya konsumsi yang lebih banyak.

\section{Pendapatan}

Pendapatan merupakan sumber penghasilan seseorang untuk memenuhi kebutuhan seharihari dan sangat penting baginya bagi kelangsungan hidup dan penghidupan secara langsung maupun tidak langsung (Suroto, 2002). Pendapatan responden yang paling dominan yaitu $\mathrm{Rp} 2.000 .000$ - Rp 3.000 .000 sebesar 67 orang (44\%), hal ini menunjukkan bahwa pendapatan $\mathrm{Rp} 2.000 .000-\mathrm{Rp}$ 3.000.000 telah melebihi UMR Kota Pontianak sehingga dapat dijadikan tolak ukur seseorang dalam pengambilan keputusan terhadap suatu produk.

\section{Jenis Kopi yang dibeli}

Kopi bubuk "Indocafe" memiliki banyak variasi rasa, diantaranya adalah Indocafe Capuccino, Indocafe Coffe Mix 3 in 1 dan Indocafe Ginseng Sereal. Jenis kopi Indocafe pertama yang sering dibeli masyarakat di Kota Pontianak adalah Indocafe Capuccino yaitu sebanyak 113 responden (75\%). Hal dikarenakan bahwa PT Sari Incofood sudah mengurangi jumlah variasi produknya yang sebagian besar hanya mendistribusikan produk kopi bubuk instan dengan tiga variasi saja yaitu Indocafe Capuccino, Indocafe Coffe Mix 3 in 1 dan sebagian kecil Indocafe Ginseng Sereal, yang menyebabkan persentase jenis kopi Indocafe lainnya mengalami penurunan. 


\section{Frekuensi Pembelian}

Tingkat frekuensi pembelian kopi bubuk instan di Kota Pontianak dapat dikategorikan rendah, hal ini dibuktikan dengan tingginya persentase pada frekuensi pembelian 1-2 kali dalam sebulan dengan jumlah setiap pembelian sebesar 3-4 bungkus. Frekunsi pembelian rendah dengan jumlah pembelian yang sedikit mengindikasikan bahwa konsumen tersebut tidak begitu tertarik sehingga tidak akan menimbulkan kepuasan pada diri konsumen (Tjiptono, 2015). Diperlukan adanya pseningkatan atribut untuk meningkatkan frekuensi pembelian yang tentunya bisa memperngaruhi kepuasan konsumen dan akan berdampak pada kesetiaannya terhadap produk tersebut.

\section{Uji Validitas dan Reabilitas Instrumen}

Uji validitas pada instrument analisis SEM terdapat 17 indikator yang terdiri dengan 43 pertanyaan. Adapun indikator yang digunakan dalam penelitian yaitu: kesadaran merek, asosiasi merek, persepsi merek, keterjangkauan harga, kesesuaian harga dengan kualitas, daya saing harga, kesesuaian harga dengan manfaat, performance, features, desain kemasan, mutu kemasan dan inovasi kemasaran, kepuasan pada produk, kepuasan manfaat, pembelian secara berulang, mau merekomendasikan dan keyakinan pada suatu produk.

Perhitungan validitas atau corrected item total correlation menunjukkan bahwa dari 43 pertanyaan yang diajukan terhadap responden dalam penelitian ini yaitu valid Serta tidak ada pengukuran yang tidak valid dengan $\mathrm{r}_{\text {hitung }}>\mathrm{r}_{\text {tabel }}$ yaitu 0,1609 pada tingkat signifikasi sebesar 5\% yang dijadikan sebagai dasar kriteria pengambilan keputusan. Selanjutnya dilakukan perhitungan reabilitas dengan nilai cronbach's alpha $>0,6$. pada hasil pengujian terhadap 43 pengukuran yang menjadi dasar pertanyaan dalam penelitian peneliti nilai cronbach's alpha sudah reabel yaitu 0,874 > 0,6 sehingga dapat dikatakan bahwa instrumen penelitian sudah konsisten.

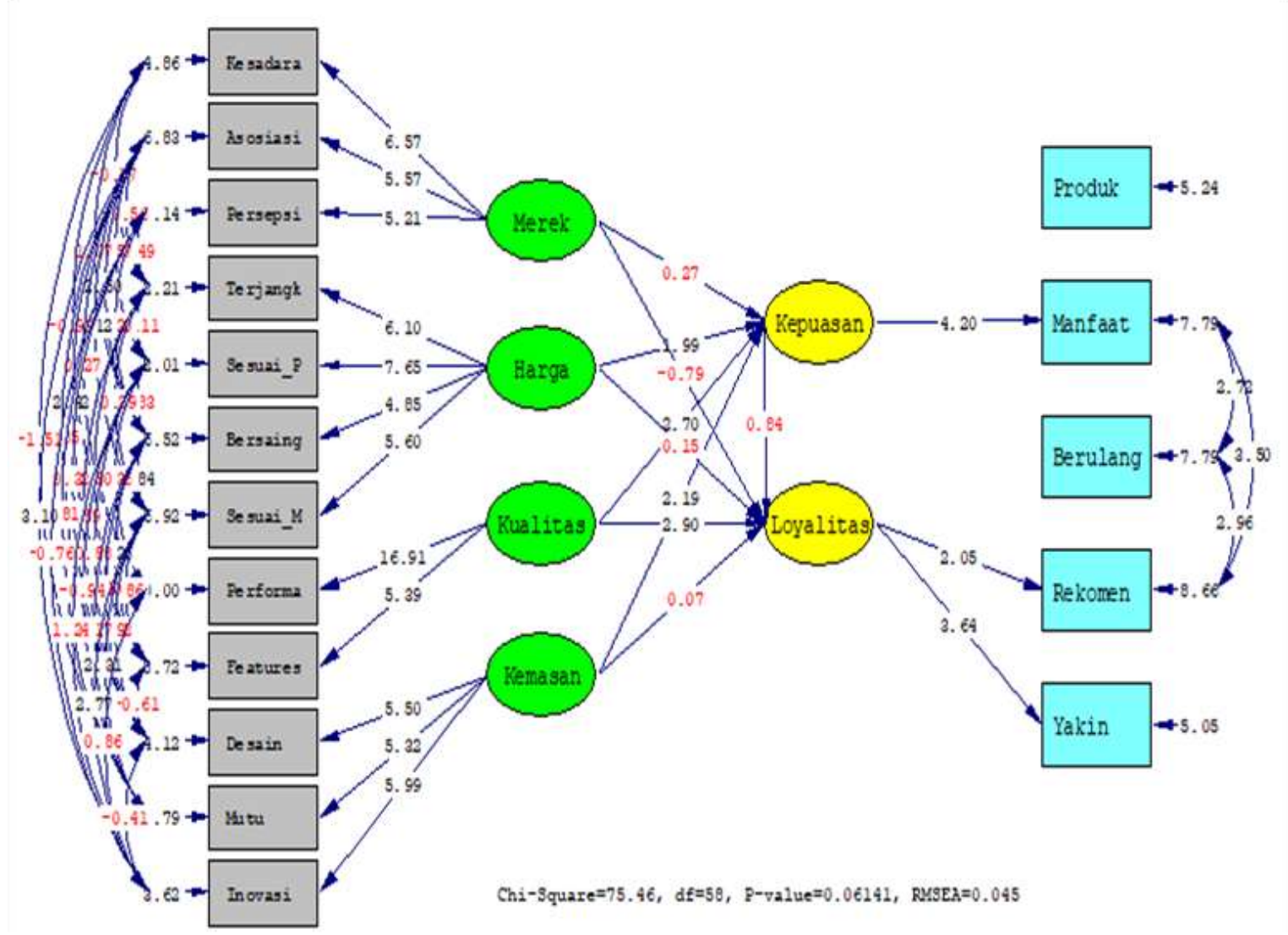

Gambar 1. Uji signifikansi t-value model SEM 


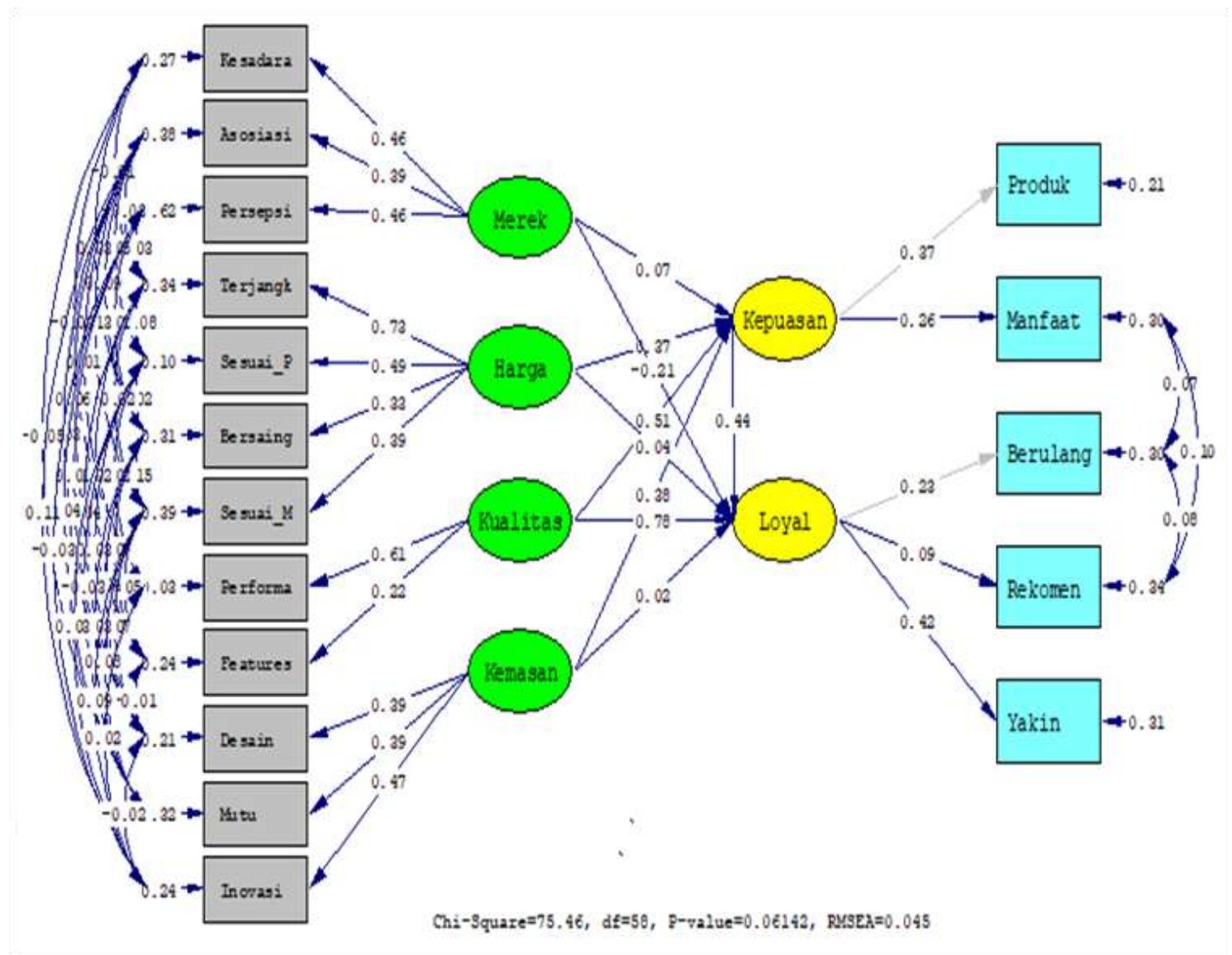

Gambar 2. Koefisien estimasi model SEM

Kecocokan Model, Analisis Structural Equation Modeling (SEM)

Uji kecocokan model (Goodness of Fit) pada model akhir terdapat 15 ukuran GOF yang menunjukkan kecocokan baik (good fit) yaitu Chi-Square/DF, NCP Interval, NCP, SNCP (NCP/n), RMSEA, ECVI, AIC, CAIC, NFI, NNFI, CFI, IFI, RMR, GFI dan PGFI, terdapat 2 yang sedang baik (marginal fit) yaitu (RFI dan AGFI) serta 2 dari 19 uji kecocokan yaitu PNFI dan CN kurang baik (bad fit). Sehingga dapat disimpulkan bahwa derajat kecocokan keseluruhan model adalah baik (good fit), karena telah memenuhi syarat pengujian goodness of fit hasil estimasi setelah direspesifikasi.

Nilai $\mathrm{R}^{2}$ yang diperoleh pada persamaan struktural variabel kepuasan (interveing) yaitu sebesar 0,78, artinya $78 \%$ varians kepuasan dapat dijelaskan oleh atribut merek, harga, kualitas dan kemasan. Sedangkan nilai $\mathrm{R}^{2}$ yang diperoleh variabel loyalitas yaitu sebesar 0,59 , artinya 59\% varians loyalitas dapat dijelaskan oleh atribut merek, harga, kualitas, kemasan dan kepuasan. Variabel kualitas berkontribusi paling besar terhadap kepuasan sekaligus loyalitas konsumen.

Penelitian Kususmasasti et al. (2017) menunjukkan bahwa variabel yang memiliki pengaruh besar yaitu kualitas produk dengan nilai pengaruh terbesar terhadap kepuasan dan loyalitas konsumen, hal tersebut dikarenakan unsur pertama yang dipertimbangkan konsumen adalah manfaat dari barang tersebut.

Merek (brand) merupakan variabel yang penting untuk mempertahankan kepuasan dan loyalitas konsumen. Nilai t-hitung merek terhadap kepuasan pada produk "Indocafe" sebesar $0,27<1,96$ sedangkan nilai t-hitung merek terhadap loyalitas sebesar 0,79 $<1,96$. Artinya secara parsial peningkatan citra merek jika dilakukan oleh "Indocafe" tidak akan meningkatkan kepuasan dan loyalitas konsumen secara signifikan. Hal ini dikarenakan kurangnya promosi baik di media sosial maupun media konveksional. Bagi konsumen merek bukan merupakan prioritas yang diutamakan, karena yang dinilai 
konsumen adalah kualitasnya bukan hanya terpaku pada merek. Menurut konsumen asal kualitas produk bagus, merek (brand) seperti apa pun itu takkan menjadi persoalan. Hal ini di dukung dengan hasil penelitian Tandenga et al. (2018) yang membuktikan bahwa merek tidak berpengaruh terhadap kepuasan dan loyalitas konsumen dalam memilih produk minuman kopi.

Harga merupakan sejumlah nilai yang ditukarkan konsumen dengan manfaat dari memiliki atau menggunakan produk yang nilainya ditetapkan oleh pembeli (Umar, 2000). Nilai $\mathrm{t}$ variabel harga terhadap kepuasan adalah sebesar 1,99>1,96 sedangkan nilai $t$ harga terhadap loyalitas sebesar $0,15<1,96$. Artinya secara parsial peningkatan harga jika dilakukan Indocafe akan meningkatkan kepuasan namun tidak dibarengi dengan rasa loyal konsumen. Hal ini dikarenakan konsumen di Kota Pontianak yang menjadi subyek penelitian sebagian besar didominasi oleh konsumen yang berada dalam kategori price consciousness sebanyak 83 orang (55\%) yaitu perilaku konsumen terhadap harga yang memiliki kecenderungan konsumen untuk mencari perbedaan harga (Pepadri, 2002). Hasil penelitian Muzaqqi et al. (2016) dan Rahmaddiansyah et al. (2015) juga membuktikan bahwa harga berpengaruh positif dan signifikan terhadap kepuasan konsumen dan keputusan konsumen dalam memilih produk minuman.

Indikator keterjangkauan bermakna atau berpengaruh dengan nilai t-hitung yaitu $(6,10>$ $1,96)$ yang dihasilkan keterjangkauan memiliki pengaruh besar mendukung mendukung komponen harga dalam membentuk kepuasan konsumen terhadap "Indocafe". Sehingga semakin suka konsumen terhadap harga yang terjangkau maka akan memiliki pengaruh yang semakin besar untuk memenuhi kepuasan konsumen. Hasil penelitian Rahmaddiansyah et al. (2015), Rahmanissa dan Sadeli (2016), Winata dan Gienardy (2013) memperlihatkan bahwa keterjangakauan memberikan kontribusi penting untuk mempengaruhi harga dalam membentuk kepuasan konsumen.

Indikator kesesuaian produk bermakna atau berpengaruh dengan nilai t-hitung sebesar $(7,65>1,96)$ yang dihasilkan paling tinggi untuk kategori indikator harga, yang dihasilkan paling tinggi untuk kategori indikator harga.
Artinya kesesuaian produk berpengaruh besar terhadap komponen harga. Sehingga semakin suka konsumen terhadap kesesuaian produk maka indikator kesesuaian produk memiliki pengaruh yang semakin besar untuk memenuhi kepuasan dan loyalitas konsumen. Pada penelitian Nargis (2015), Yulisa et al. (2013), serta Rahmanissa dan Sadeli (2016) juga memperlihatkan bahwa kesesuaian produk memberikan peran penting pada konsumen sebagai pertimbangan utama dan pertama dari konsumen sebelum membeli sebuah produk atau jasa.

Indikator bersaing berpengaruh pada faktor harga dengan nilai t-hitung yaitu $(4,85>$ 1,96) yang dihasilkan oleh daya saing berpengaruh besar. Artinya daya saing berpengaruh positif terhadap komponen harga. Hal ini dikarenakan Indocafe memberikan gift dan potongan harga apabila konsumen membeli dalam jumlah yang lebih banyak. Hal ini di dukung dengan hasil penelitian Runtunuwu et al. (2014) menunjukkan bahwa indikator daya saing berpengaruh secara positif terhadap harga untuk memenuhi kepuasan dan loyalitas konsumen. Sehingga diperlukan perusahaan selalu menjaga harga agar tetap bersaing.

Indikator sesuai manfaat berpengaruh pada faktor harga dengan nilai t-hitung yaitu $(5,60>1,96)$ yang dihasilkan oleh kesesuaian manfaat berpengaruh besar. Artinya kesesuaian manfaat berpengaruh positif terhadap komponen harga. Hal ini dikarenakan menurut responden, merasakan mengkonsumsi "Indocafe" dapat memberikan manfaat seperti menghilangkan stress dan lelah. Pradinata (2017) menyatakan bahwa kesesuaian manfaat memiliki peranan penting bagi konsumen, demikian pula Puspita et al. (2015) menjelaskan bahwa responden dalam mengkonsumsi kopi dapat memberikan manfaat fungisonal dan psikologis.

Kualitas produk merupakan suatu penilaian konsumen terhadap keunggulan atau keistimewaan suatu produk dan memiliki peranan yang penting untuk mempertahankan kepuasan dan loyalitas konsumen Tjiptono dan Diana (2003). Nilai t-hitung faktor kualitas terhadap kepuasan konsumen kopi bubuk instan "Indocafe" sebesar 2,70>1,96 dengan koefisien estimasi 0,51 sedangkan t-hitung kualitas terhadap loyalitas adalah sebesar 2,90 > 1,96 dengan koefisien estimasi 0,78 yang 
berarti bahwa faktor kualitas berpengaruh atau signifikan terhadap kepuasan dan loyalitas konsumen. Jadi apabila komponen kualitas ditingkatkan maka akan mempengaruhi kepuasan dan loyalitas konsumen terhadap kopi "Indocafe". Faktor kualitas diukur oleh indikator performance dan features. Pada penelitian Kususmasasti et al. (2017) serta Wulandari dan Mudiantono (2013) mengungkapkan bahwa variabel yang memiliki pengaruh besar yaitu kualitas produk dengan nilai paling besar.

Indikator performance mendukung komponen kualitas dengan nilai t-hitung yaitu $(16,91>1,96)$ yang memiliki pengaruh pengaruh paling besar dibandingkan semua indikator lain. Artinya performance berpengaruh terhadap komponen harga. Kualitas memiliki perananan yang sangat penting untuk ditindak lanjuti karena sebagai besar konsumen menaruh perhatian lebih terhadap indikator tersebut. Berdasarkan evaluasi di lapangan, sebagian besar konsumen menilai bahwa Indocafe memiliki fitur produk dan harga sesuai, dapat memberikan energi dan berkonsentrasi dan aftertaste yang mampu bertahan lama sehingga membuat konsumen merasa nyaman dan mempunyai kesan yang baik terhadap "Indocafe". Didukung oleh penelitian Diwangkoro (2017) menunjukkan bahwa indikator performance berpengaruh secara positif terhadap kualitas untuk memenuhi kepuasan konsumen. Sehingga semakin terpenuhi kesukaan dan kepuasan konsumen terhadap performance yang diberikan maka akan memiliki pengaruh yang semakin besar terhadap kepuasannya.

Indikator features berkontribusi pada kualitas dengan nilai t-hitung $(5,39>1,96)$ yang dihasilkan oleh features, sehingga hubungan features pada kualitas dalam kepuasan konsumen kopi "Indocafe" bermakna atau berpengaruh. Hal ini disebabkan oleh sebagian besar konsumen menganggap bahwa Indocafe memiliki komposisi 'atau kandungan yang baik, taste yang balance antara rasa manis, asam dan pahit, flavour yang memikat dan warna yang baik, aroma kuat yang mewakili kopi serta tekstur kopi yang halus tidak berampas dan cepat larut membuat konsumen merasa terpenuhi keinginannya atau merasakan kepuasan dan mempunyai image yang baik terhadap produk tersebut. Didukung oleh penelitian Rahmanissa dan Sadeli (2016) serta Annishia dan Setiawan (2018) menunjukkan bahwa indikator features berpengaruh positif terhadap kualitas sebagai upaya memenuhi kepuasan dan loyalitas konsumen.

Kemasan merupakan informasi yang mampu memberikan dorongan pada pembelian untuk membaca dulu dan berfikir untuk membeli sehingga memberikan kontribusi yang penting sebagai strategi dalam memasarkan produk (Suyitno, 1996). Nilai t-hitung kemasan terhadap kepuasan pada produk "Indocafe" sebesar 2,19>1,96 dengan koefisien estimasi sebesar 0,38 yang berarti bahwa kemasan berpengaruh signifikan terhadap kepuasan konsumen. Jadi apabila faktor kemasan ditingkatkan maka akan mempengaruhi kepuasan konsumen terhadap Indocafe. Sedangkan nilai t-hitung kemasan terhadap loyalitas yaitu sebesar $0,07<1,96$. Artinya apabila komponen kemasan ditingkatkan $1 \%$ maka tidak akan terlalu membuat konsumen loyal. Hal ini dikarenakan bahwa kemasan yang terdiri atas indikator desain grafis, informasi produk dan asosiasi saja tidak cukup untuk dapat mempengaruhi konsumen agar merasa loyal. Berdasarkan evaluasi dilapangan konsumen tidak hanya memperhatikan komponen kemasan saja, melainkan dengan mempertimbangkan komponen lain selain kemasan. Konsumen tidak memperhatikan kemasan bentuk fisik produk yang menurutnya tidak memberikan manfaat berlebih.

Indikator desain berpengaruh terhadap kemasan dengan nilai t-hitung $(5,50>1,96)$ yang dihasilkan oleh desain, sehingga hubungan desain pada faktor kemasan terhadap kepuasan "Indocafe" bermakna atau berpengaruh. Sebagaian besar responden setuju menganggap bahwa desain kemasan Indocafe sudah cukup baik. Hal ini disebabkan konsumen menilai tampilan kemasan enak dilihat, posisi tifografi gambar tulisan yang sudah sesuai. Sejalan dengan penelitian Medikana et al. (2018) menyatakan bahwa desain berpengaruh positif terhadap kemasan sehingga apabila desain ditingkatkan maka nilai kemasan di mata konsumen semakin baik.

Indikator mutu berkontribusi pada faktor kemasan dengan nilai t-hitung 5,32>1,96 yang dihasilkan oleh mutu, sehingga hubungan mutu pada faktor kemasan terkait kepuasan konsumen bermakna atau berpengaruh. Hal ini 
disebabkan berdasarkan informasi dari responden, "Indocafe" sudah memiliki kejelasan informasi produk terkait kandungan nutrisi, tanggal produksi dan informasi kadaluarsa produk. Sejalan dengan penelitian Setiawan dan Andayani (2016) yang menunjukkan bahwa indikator mutu berpengaruh secara positif terhadap kemasan dalam memenuhi kepuasan konsumen.

Indikator inovasi berkontribusi pada kemasan dengan nilai t-hitung 5,99>1,96 yang dihasilkan oleh inovasi, sehingga hubungan inovasi pada kemasan terkait kepuasan konsumen bermakna atau berpengaruh. Hal ini disebabkan oleh keadaan konsumen yang lebih memilih inovasi-inovasi yang lebih beragam terhadap kemasan agar memiliki identitas tersendiri sehingga mudah dikenali dan dibedabedakan dengan produk sejenis lainnya. Inovasi kemasan berpengaruh sebesar $47 \%$ yang merupakan salah satu atribut yang sangat penting dan perlu mendapat perhatian. Sejalan dengan penelitian Lukman (2014) serta Isnaeni dan Sanaji (2016) yang menyimpulkan bahwa inovasi berpengaruh secara positif terhadap kemasan yang akan berimbas pada kepuasan dan loyalitas konsumen.

Kepuasan konsumen merupakan salah satu faktor penting yang perlu diperhatikan perusahaan karena konsumen merupakan alasan mengapa suatu perusahaan dapat eksis, dengan tingkat kepuasan konsumen yang tinggi selanjunya akan berdampak pada meningkatkan loyalitas konsumen (Fornell et al. 1996). Nilai t-hitung kepuasan terhadap loyalitas sebesar $0,84<1,96$. Artinya secara parsial jika peningkatan kepuasan dilakukan oleh "Indocafe" melalui upaya peningkatan secara bersama-sama variabel merek, harga, kualitas dan kemasan tidak membuat konsumen loyal terhadap produk, yang berarti Indocafe hanya berhenti sampai kepada tahap kepuasan saja namun tidak berarti membuat konsumen loyal terhadap produk. Hal ini sejalan dengan penelitian Dewi et al. (2020) yang menyimpulkan bahwa kepuasan tidak menjamin loyalitas konsumen kopi bubuk instan.

\section{KESIMPULAN}

Hasil penelitian menunjukkan bahwa untuk meningkatkan kepuasan konsumen sebaiknya produsen Indocafe memperhatikan atributatribut harga, kualitas dan kemasan. Sedangkan untuk mempertahankan loyalitas konsumen yaitu dengan mempertahankan serta meningkatkan kualitas produk. Hasil penelitian ini menunjukkan atribut yang memiliki kontribusi paling besar yaitu kualitas produk dalam mempengaruhi kepuasan sekaligus loyalitas konsumen, kualitas memiliki peranan yang sangat penting untuk ditindak lanjuti karena sebagian besar konsumen menaruh perhatian lebih terhadap komponen tersebut. Indikator kualitas yang diperhatikan konsumen merupakan performance dan features berupa komposisi atau kandungan kopi, taste yang balance, aroma yang kuat, tekstur yang tidak berampas dan cepat larut serta aftertaste rasa kopi yang dapat bertahan lama. Sehingga kualitas merupakan komponen yang penting untuk menjadi perhatian produsen. Karena dengan semakin ditingkatkannya kualitas maka akan meningkatkan kepuasan sekaligus Indocafe menimbulkan kesetiaan konsumen di Kota Pontianak.

\section{DAFTAR PUSTAKA}

Anninshia, F. B., \& Soekarno, M. (2018). Pengaruh kualitas produk kopi terhadap kepuasan konsumen di Jade Lounge Swiss Belresidences Kalibata Jakarta. Jurnal Hospitality dan Pariwisata, 4(1), $1-10$.

Badan Pusat Statistik. (2019). Kalimantan Barat dalam angka. Badan Pusat Statistik. Pontianak: BPS.

Dewi, Eka, Setia, T., Muslim, Wijaya, \& Marbun, P. (2020). The influence of lifestyle, physical environment, and menu variety on customer loyalty through customer satisfaction in the coffee shop. International Journal of Research and Review, 7(3), 102-110.

Diwangkoro, E., \& Murniati, D. E. (2017). Tingkat kepuasan konsumen terhadap kualitas kopi dan kualitas pelayanan di Kafe Kopi Garasi Candi Wirangun Ngaglik Sleman Yogyakarta. Jurnal Pendidikan Teknik Boga, 6(2), 1-4. 
Engel, James, F., Roger, D. B., \& Paul, W. M. (2001). Perilaku Konsumen (Jilid 2 ed.). Jakarta: Binarupa Aksara.

Fornell, C., Johnson, M., \& Eugene. (2000). The American Custumer Satisfaction Index: nature, purpose and findings. Journal of Marketing, 60(4), 7-17.

Isnaeni, Muchammad, A., \& Sanaji. (2016). Pengaruh inovasi produk terhadap loyalitas dengan kepuasan konsumen sebagai variabel intervening (studi pada konsumen Kafe Fruit Coffee Refresho di Julung Agung). Jurnal Ilmu Manajemen, 4(2), 5-9.

Kotler, Philip, \& Amstrong, G. (2006). Manajemen Pemasaran (12 ed.). Jakarta: Erlangga.

Kotler, Philip, \& Keller, K. (2009). Dalam Manajemen Pemasaran (Jilid 1 ed.). Jakarta:: Erlangga.

Kusumasasti, I., Andarwati, \& Hadiwidjojo, D. (2017). Pengaruh kualitas produk dan layanan terhadap loyalitas pelanggan coffee shop. Jurnal Ekonomi Bisnis, 22(2), 4-6.

Lilja, J. (1994). Consumer Behaviour. International Journal of Pharmacy Practice, 2(4), 192-93. doi:10.1111/j.20427174.1994.tb00761.x.

Lukman, M. D. (2014). Analisis pengaruh ekuitas merek terhadap keputusan pembelian dan kepuasan konsumen produk Teh Botol Sosro kemasan kotak. Jurnal Administrasi Bisnis, 10(1), 12-17.

Medikana, Ari, I., \& Ustriyana, I. (2018). Variabel-variabel yang mempengaruhi kepuasan dan keputusan pembelian ulang pada Kopi Made. Journal of Agribusiness Management, 6(2), 31. doi:10.24843/jma.2018.v06.i02.p05

Muzaqqi, A., Fauzi, A., \& Suyadi, I. (2017). Pengaruh kesadaran merek, kesan kualitas, asosiasi merek dan loyalitas merek terhadap ekuitas merek (survei kepada konsumen pembeli dan pengguna produk Sari Apel SIIPLAH di Perumahan Saxophone Kecamatan Lokowaru Kota Malang). Jurnal Administrasi Bisnis, 31(1), 2-8.

Nargis, L. (2015). Faktor-faktor yang mempengaruhi kepuasan konsumen terhadap kopi bubuk di Kota Palembang. Jurnal Kompetitif, 4(2), 4-11.

Pepadri, I. (2002). Pricing is the moment of truth. Jurnal Usawan, 16(10), 1-5.

Pradinata, J. (2017). Analisis kepuasan dan loyalitas konsumen Kopi Nefo Cap Aaa di Kabupaten Kerinci. Jurnal Ekonomi Islam, 8(2), 8-15.

Puspita, Intan, Achmad , F., \& Kadarisman , H. (2015). Pengaruh atribut produk terhadap psikologis konsumen yang berdampak terhadap keputusan pembelian (studi pada konsumen Kopi Kapal Api Jl. Jaksa Agung Suprapto Gang 1 RW.02 Kelurahan Samaan Kecamatan Klojen Kota Malang Provinsi Jawa Timur). Jurnal Administrasi Bisnis, 25(1), 1-8.

Rahmadiansyah, \& Fajri. (2015). Analisis loyalitas konsumen terhadap minuman kopi robusta di Kota Banda Aceh. Jurnal Agrisep, 16(2), 6-10.

Rahmanisa, R., \& Sadeli, A. (2015). Kepuasan konsumen terhadap atribut kualitas minuman kopi di Java Preanger Coffee House Bandung. Jurnal Agribisnis dan Sosial Ekonomi Pertanian, 11(1), 6-10.

Runtunuwu, J. G., Oroh, S., \& Tarordi, R. (2016). Pengaruh kualitas produk, harga dan kualitas pelayanan terhadap kepuasan pengguna Cafe dan Resto Cabana Manado. Jurnal EMBA, 2(2), $10-15$.

Setiawan, E., \& Andayani, S. A. (2016). Analisis kepuasan konsumen (studi kasus pada Kedai Kopi di wilayah Majalengka). Jurnal Ilmu Pertanian dan Peternakan, 4(2), 7-11.

Solikatun, Kartono, D. T., \& Demartoto, A. (2015). Perilaku konsumsi kopi sebagai 
budaya masyarakat konsumsi : studi fenomenologi pada peminum kopi di Kedai Kopi Kota Semarang. Jurnal Analisa Sosiologi, 4(1), 60-74.

Solomon, M. (2002). Consumer Behavior: Buying, Vaving and Being. New Jersey: Prentice Hall.

Sugianto, Garra, Mustamu, H., \& Ronny. (2013). Strategi bersaing pada perusahaan kopi. Jurnal Agora, 1(3), 510.

Suroto. (2002). Strategi Pembangunan dan Perencanaan Kesempatan Kerja. Yogyakarta: Gadjah Mada University Press.

Suyitno. (1996). Pemasaran Wisata Tour Planning. Yogyakarta: Kanisius.

Tandega, R., Lapian, J., \& Soegoto, A. (2018). Pengaruh citra merek dan kualitas produk terhadap kepuasan pengguna kopi bubuk Fortorang pada PT. Fortuna Inti Alam. Jurnal EMBA, 6(3), 11-15.

Tjiptono, \& Fandy. (2015). Strategi Pemasaran (4 ed.). Yogyakarta: Andi Offset.

Tjiptono, F., \& Diana, A. (2000). Total Quality Management. Yogyakarta: Andi.

Top Brand Award. (2020). Retrieved from https://www.topbrand-award.com/topbrand-index/.
Umar, H. (2000). Riset Pemasaran dan Penilaian Konsumen. Jakarta: PT Gramedia Pustaka.

Utama, Herdiana, D., \& Amelia , F. (2009). Pengaruh atribut produk terhadap kepuasan pelanggan produk Teh Celup Sosro dan 2 Tang (survei pada pelanggan Teh Celup di Griya Pahlawan dan Giant Pasteur Bandung). Jurnal Pendidikan Manajemen Bisnis, 8(16), 30-40.

Winata, A. S., \& Gienardy, R. (2015). Analisa persepsi konsumen terhadap harga, kualitas produk dan suasana di Cafe My Kopi O. Jurnal Hospitality dan Manajemen, 1(2), 4-8.

Wulandari, N., \& Mudiantono. (2013). Produk, kualitas pelayanan dan lokasi terhadap kepuasan konsumen. JEAM, 2(3), 7-9.

Yulianti, Yanti, \& Deliana, Y. (2018). Gaya hidup kaitannya dengan keputusan konsumen dalam membeli minuman kopi. Jurnal Agrisep, 17(1), 39-50. https://doi.org/10.31186/jagrisep.17.1.39 -50 .

Yulisa, L., Indriani, Y., \& Situmorang, S. (2013). Perilaku konsumsi mahasiswa Universitas Lampung terhadap kopi instan siap saji. JIIA, 1(4), 4-7. 